\title{
Cr-poor Megacrysts from the Frank Smith Mine and the source regions of transitional kimberlites.
}

\author{
Bell, D. R. and Mofokeng, S.W.
}

Department of Geological Sciences, University of Cape Town, Rondebosch 7700, South Africa.

Introduction. Two varieties of kimberlite, groups I and II - now termed kimberlite and orangeite, respectively, by Mitchell (1995) - have long been recognized and were formally distinguished on geochemical grounds by Smith (1983) and Smith et al (1985). The source regions of these two types have been of great interest, because they appear quite distinct and must reveal something important about heterogeneity in the mantle beneath the continents where they occur. Determining their physical location will contribute a great deal to understanding the petrogenesis of kimberlites. As with most rock classification schemes, intermediate or transitional rock types exist which provide an opportunity to explore the relationship between the principal categories. It was recognized as early as Wagner (1914) that certain kimberlites of the Barkly-West area of the Northern Cape, South Africa, including the Frank Smith Mine (FSM) displayed features intermediate between group I and group II kimberlites. Skinner (1989) has discussed several further examples in southern Africa. Here, we report intitial results of a study aimed at understanding the origin of the FSM transitional kimberlite and the nature of its source region, based on geochemical analysis of the mantle-derived and potentially cognate megacryst suite.

The Frank Smith Mine kimberlite. The Frank Smith kimberlite near Barkly West was noted by Wagner (1914) to exhibit a petrographic character intermediate between true micaceous kimberlites and the archetypal kimberlites of the Kimberley type area. It occurs in close proximity $( \pm 2 \mathrm{~km})$ to the group II Sover-Doornkloof fissures and is the same age $(114 \pm 2$ m.y. - Smith et al 1985b) as the nearby Newlands group II kimberlite and similar to other group II kimberlites of the region, yet older than dated group I kimberlites in the general area ( \pm 90 m.y.). The Sr and Nd isotopic character of the kimberlite is however intermediate between Group I and II kimberlites (Smith 1983). In contrast to group II kimberlites of the area which are characterized by eclogite-dominated xenolith suites, the Frank Smith contains a diverse assemblage of peridotite xenoliths and Cr-poor megacrysts (Boyd 1974a,b, Pasteris et al 1979) (in addition to occasional eclogites). This xenolith association is much more typical of group I kimberlites. This unusual combination of features of both group I and group II kimberlites in the Frank Smith Mine makes it an ideal candidate for investigations aimed at understanding the petrogenetic processes of kimberlite formation and of the spatial distribution of group I and group II kimberlite sources in the mantle.

The Cr-poor megacryst (discrete nodule) suite. This suite, comprising Cr-poor megacrysts of garnet, ilmenite, olivine, enstatite, diopside and lamellar pyroxene-ilmenite intergrowths, has been described previously by Boyd (1974a,b) and Pasteris et al (1979) and is similar to that seen in typical group I kimberlites from northern Lesotho and the Monastery Mine. In more recent years it has become apparent that Cr-poor megacrysts (mostly garnets) are relatively widespread in Group II kimberlite (orangeite) and that the composition of these megacrysts is different from those in group I kimberlites (Moore and Gurney 1991, Bell et al. 1995, De Bruin 1995). Numerous studies on these and similar suites in related alkaline ultramafic 
rocks suggest that these megacrysts are the crystallization products of magmas which bear some relationship to the erupted host rocks, precipitated in pegmatitic veins in the deeper levels sampled by the host magmas. Isotopic studies (Smith et al 1995) clearly indicate that megacrysts share geochemical characteristics with the kimberlite source region and may therefore be used to study these features without the complicating assimilation and alteration effects which influence kimberlite magmas on ascent and emplacement.

Philosophy and methods. A re-examination of the FSM megacryst suite was undertaken in order to determine whether these deep-seated samples also reflect transitional features. It was noted that discrete clinopyroxene megacrysts are very rare amongst the megacryst suite, despite the fact that clinopyroxene - ilmenite intergrowths and clinopyroxene inclusions in garnets are relatively common. A discrepancy between discrete and associated cpx abundances is typical of megacryst suites in group II kimberlites and may reflect greater instability of cpx in group II-like magmas. Initial major element analyses confirmed some cpx compositions intermediate between group I and group II megacrysts and argued for a deep-seated origin for the transitional kimberlite character. Based on these observations, a more comprehensive study was initiated with the hope that, by monitoring the acquisition of the transitional character during their evolution, the megacrysts could provide new information on the location of group I and group II sources (or a discrete transitional source) in the mantle. Major and trace element concentrations were determined in megacryst minerals by electron- and ion-microprobe at the University of Cape Town and the Carnegie Institution of Washington and compared with similar analyses of the Monastery (Group I) and Lace (Gp II) megacryst suites (Bell et al 1995 and unpubl.).

Results. The Frank Smith megacrysts display a great deal of compositional complexity. Some elements and interelement ratios are similar to those of group I megacrysts throughout their range of compositions, some elements are similar in concentration to group II megacrysts, some are intermediate and some show a progressive evolution from group I like to group II like concentrations with increasing $\mathrm{Ca} / \mathrm{Ca}+\mathrm{Mg}(\mathrm{Ca})$ in cpx (decreasing temperature): In $\mathrm{cpx}, \mathrm{Ca}, \mathrm{Mg}, \mathrm{Fe}, \mathrm{Cr}$ and $\mathrm{Ni}$ show features of both group I and II suites as well as intermediate compositions. Ca\# vs Mg\# relations show an evolution from group Ilike compositions through intermediate compositions in cpx-ilmenite intergrowths to more group II like compositions, with $\mathrm{Mg} \#$ relatively constant. This evolution is difficult to explain in a simple, closed system fractional crystallization scenario and suggests processes of wall rock interaction in megacryst evolution.

$\mathrm{Ti}, \mathrm{Ba}$ and $\mathrm{Sr}$ are similar to group I cpx's as are most cpx-controlled trace element ratios (e.g., $\mathrm{Sr} / \mathrm{Ce}$ ). $\mathrm{Sr}$ and $\mathrm{Nd}$ isotope compositions are also more similar to group I cpx megacrysts and indicate substantial disequilibrium with the transitional type magma (Smith et al 1995). $\mathrm{K}, \mathrm{Zr}$ and $\mathrm{Hf}$ overlap group I cpx concentrations in some samples, but are intermediate to the Lace suite in others. $\mathrm{Li}$ and $\mathrm{Be}$ range from intermediate to group II concentrations, whereas the HREE and Y are exclusively group II-like. LREE and Sr concentrations are similar in all three suites but the trend (slope on element vs. Ca\# plots) of compositional evolution of FSM cpx's parallels those from Lace.

High precision electron microprobe determinations of $\mathrm{K}$ in $\mathrm{cpx}$ were made, revealing two groups on the basis of $\mathrm{K}$ content. A lower $\mathrm{K}$ group overlaps typical group I cpx concentrations, while a higher concentration group ( $>240 \mathrm{ppm} \mathrm{K}$ ) is unique among cpx megacrysts from 27 African group I kimberlites and therefore likely to indicate a different source composition, which may be uniquely characteristic of transitional kimberlite. (Group II megacryst cpx contains far higher $\mathrm{K}$ than either of the FSM cpx populations). The existence 
of discrete, slightly different populations of Cr-poor megacrysts within a single kimberlite pipe has been demonstrated by De Bruin (1993) and the present case may be a more extreme example of this phenomenon.

It can be shown that trace element compositional trends in kimberlite megacrysts are strongly influenced by mineral crystal chemistry and are not simple indices of magmatic evolution as usually assumed. This introduces considerable complexity into the quantitative interpretation of the above trends in which we seek to unravel competing effects of thermal regime (group II megacrysts are typically lower T) and bulk (source region ) composition. Element concentrations in FSM megacrysts thus appear to be a complex function of partitioning and bulk hybridization effects which belie simple closed system fractional crystallization scenarios. The FSM megacryst magma and kimberlite appears to contain chemical components from two sources and to have evolved in a physical setting which spans conditions characteristic of both group I and group II megacrysts.

\section{References}

Bell, D.R., Schulze, D.J., Read, G.H., Mattioli, G.S., Shimizu, N., Moore, R.O. and Gurney, J.J. 1995. Extd Abstrs, 6th International Kimberlite Conference, Novosibirsk, .52-54.

Boyd, F.R. 1974a Carnegie Inst Washington Yearb. 73, 285-293.

Boyd, F.R. 1974b Carnegie Inst Washington Yearb. 73, 282-285.

De Bruin, D. 1993 Megacrysts from the Schuller kimberlite, R.S.A. Bull Geol. Surv S.Afr. De Bruin, D. 1995. Extd Abstrs. 6th Internat. Kimberlite Conf., Novosibirsk, 71-73.

Mitchell, R.H. 1995 Kimberlites, Orangeites and related rocks, Plenum.

Moore R.O. and Gurney, 1991. Extd. Abstrs., 5th International Kimberlite Conf., Araxa.

CPRM Spec Publ. 2/91, Brasilia, 298-300.

Pasteris, J.D., Boyd, F.R. and Nixon, P.H. 1979. In Boyd, F.R. and Meyer, H.O.A. (eds) The Mantle Sample: Inclusions in kimberlites and other volcanics. AGU, Washington, 265278.

Skinner, E.M.W. 1989. Geol Soc. Australia Spec. Publ. 14, 528-544.

Smith C.B. Nature 304, 51-54.

Smith, C. B., Gurney, J.J., Skinner, E.M.W., Clement, C.R. and Ebrahim, N. 1985a. Trans. Geol. Soc. S. Afr. 88, 267-280.

Smith, C.B., Allsopp, H.L. Kramers, J.D., Hutchinson, G. and Roddick, J.C., 1985b. Trans. Geol. Soc. S. Afr. 88, 249-256.

Smith, C.B., D.J Schulze., D. R. Bell and K.S. Viljoen 1995 Extd. Abstrs, 6th International

Kimberlite Conference, Novosibirsk. 546-548.

Wagner, P.A. 1914. The Diamond Fields of South Africa. C. Struik, Cape Town. 